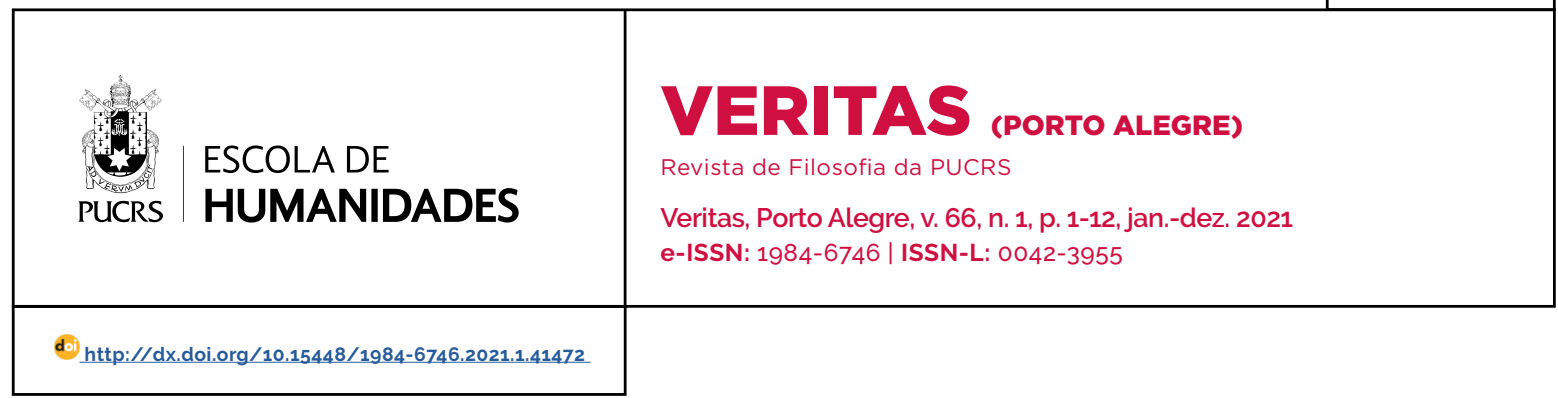

SEÇÃO EPISTEMOLOGIA \& FILOSOFIA DA LINGUAGEM

\title{
Does anti-reductionism in the epistemology of testimony imply interest relativism about knowledge attributions?
}

\author{
O anti-reducionismo na epistemologia do testemunho implica relativismo de interesse \\ sobre atribuições de conhecimento? \\ ¿El antirreduccionismo en la epistemologia del testimonio implica un relativismo de \\ interés sobre las atribuciones del conocimiento?
}

\author{
John Greco ${ }^{1}$ \\ orcid.org/0000-0002-4586-3403 \\ john.greco@georgetown.edu
}

Received on: 30 jun. 2021. Approved on: 10 set. 2021. Published on: 27 dez. 2021

\section{(c) (1)}

Artigo está licenciado sob forma de uma licença Creative Commons Atribuição 4.0 Internacional.

\begin{abstract}
Anti-reductionism in the epistemology of testimony is the thesis that testimonial knowledge is not reducible to knowledge of some other familiar kind, such as inductive knowledge. Interest relativism about knowledge attributions is the thesis that the standards for knowledge attributions are relative to practical contexts. This paper argues that anti-reductionism implies interest relativism. The notion of "implies" here is a fairly strong one: anti-reductionism, together with plausible assumptions, entails interest relativism. A second thesis of the paper is that anti-reductionism in the epistemology of testimony creates significant pressure toward attributor contextualism (a version of interest relativism). Even if anti-reductionism does not strictly entail attributor contextualism, the most powerful motivations for anti-reductionism also motivate attributor contextualism over alternative positions.
\end{abstract}

Keywords: Contextualism. Invariantism. Reductionism. Relativism. Anti-reductionism. Testimony.

Resumo: O anti-reducionismo na epistemologia do testemunho é a tese de que o conhecimento testemunhal não é redutivel ao conhecimento de algum outro tipo familiar, como o conhecimento indutivo. O relativismo de interesse sobre atribuições de conhecimento é a tese de que os padrões para atribuições de conhecimento são relativos a contextos práticos. Este artigo argumenta que o anti-reducionismo implica o relativismo de interesse. A noção de "implicação" aqui é bastante forte: o anti-reducionismo, junto com suposições plausiveis, acarreta logicamente o relativismo de interesse. Uma segunda tese do artigo é que o anti-reducionismo na epistemologia do testemunho cria uma pressão significativa em direção ao contextualismo do atribuidor (uma versão do relativismo de interesse). Mesmo que o anti-reducionismo não acarrete estritamente o contextualismo do atribuidor, as motivações mais poderosas para o anti-reducionismo também motivam o contextualismo do atribuidor em vez de posições alternativas.

Palavras-chave: Contextualismo. Invariantismo. Reducionismo. Relativismo. Anti-reducionismo. Testemunho.

Resumen: El antirreduccionismo en la epistemologia del testimonio es la tesis de que el conocimiento testimonial no se puede reducir al conocimiento de algún otro tipo familiar, como el conocimiento inductivo. El relativismo de interés sobre las atribuciones de conocimiento es la tesis de que los estándares para las atribuciones de conocimiento son relativos a contextos prácticos. Este artículo sostiene que el antirreduccionismo implica el relativismo de intereses. La noción de "implicación" aqui es bastante fuerte: el antirreduccionismo, junto con los supuestos plausibles, implica lógicamente el relativismo de intereses. Una segunda tesis del artículo 
es que el antirreduccionismo en la epistemología del testimonio crea una presión significativa hacia el contextualismo del atribuidor (una versión del relativismo del interés). Incluso si el anti-reduccionismo no implica estrictamente el contextualismo del atribuidor, las motivaciones más poderosas para el anti-reduccionismo también motivan el contextualismo del atribuidor sobre posiciones alternativas.

Palabras clave: Contextualismo. Invariantismo. Reduccionismo. Relativismo. Anti-reduccionismo. Testimonio.

Let "Anti-Reductionism" in the epistemology of testimony be the thesis that testimonial knowledge is not reducible to knowledge of some other familiar kind, such as inductive knowledge. Let "Interest Relativism" about knowledge attributions be the thesis that the standards for knowledge attributions are relative to practical contexts. For example, Attributor Contextualism, a familiar form of Interest Relativism, holds that the truth-values of knowledge attributions vary across attributor contexts, and this because different attributor contexts are associated with different practical contexts. In this paper, I will argue that Anti-Reductionism implies Interest Relativism. The notion of "implies" here is a fairly strong one: Anti-Reductionism in the epistemology of testimony, together with plausible assumptions, entails Interest Relativism about knowledge attributions. The central thesis of the paper can therefore be reformulated as follows: If you are an anti-reductionist about testimonial knowledge, you have to be an interest relativist about knowledge attributions. ${ }^{2}$

A second thesis of the paper is that Anti-Reductionism in the epistemology of testimony creates significant pressure toward Attributor Contextualism about knowledge attributions. Even if Anti-Reductionism does not strictly entail Attributor Contextualism, the most powerful motivations for Anti-Reductionism also motivate Attributor Contextualism over alternative positions.

Section 1 and 2 clarify the commitments of Anti-Reductionism and Interest Relativism, respectively. Section 3 puts forward an argument in favor of the thesis that Anti-Reductionism implies Interest Relativism. The basic idea is that any plau- sible version of Anti-Reductionism must allow that some testimonial knowledge qualifies as inductive knowledge. That is, some testimony-based beliefs qualify as knowledge only because they meet the standards of inductive knowledge. But then, on any plausible version of Anti-Reductionism, some testimonial knowledge meets the standards of inductive knowledge and some does not. Now add a second assumption: that which standards apply is determined by features of the practical context in which the testimonial exchange takes place. These considerations are sufficient to show that Anti-Reductionism implies Interest Relativism.

Section 4 considers an argument for a stronger thesis-that Anti-Reductionism implies Attributor Contextualism. The argument proceeds by showing that, if Anti-Reductionism is true, then an interesting kind of case, with a particular kind of structure, is possible. Namely, it is possible for the same hearer to occupy different practical contexts, and to be subject to different standards for testimonial knowledge, depending on which practical context is relevant. Next, it is argued that such a case is consistent with Attributor Contextualism but inconsistent with the standard competitors to Attributor Contextualism-Traditional Invariantism and Subject Sensitive Invariantism. This argument does not go through, however, because Attributor Contextualism and its standard competitors do not exhaust all possible positions. Specifically, Stephen Grimm's "rising tides" view constitutes a version of interest-relative invariantism and is consistent with the kind of case under consideration. Nevertheless, it is argued, the most powerful motivations for Anti-Reductionism also motivate Attributor Contextualism over Grimm's "rising tides" view and other alternatives. The conclusion is that, although Anti-Reductionism does not strictly imply Attributor Contextualism, the former position creates significant pressure towards adopting the latter. Put differently: If you are an anti-reductionist about testimonial knowledge, you have good reason to be an attributor contextualist about knowledge attributions.

\footnotetext{
2 Here and throughout I use the term "knowledge attributions" to refer to linguistic entities. Specifically, knowledge attributions are linguistic vehicles for ascribing (or denying) knowledge.
} 


\section{Reductionism and Anti-reductionism in the epistemology of testimony}

The label "anti-reductionism" is applied to various positions in the epistemology of testimony. ${ }^{3}$ But a standard and well-motivated meaning of the term is the following: At least some testimonial knowledge is not reducible to knowledge of some other familiar kind, such as inductive knowledge. ${ }^{4}$ One way to better understand the commitments of anti-reductionism, so understood, is to consider the position that it is denying. Namely, "reductionism" in the epistemology of testimony is the thesis that testimonial knowledge can be reduced to knowledge of some other kind. The relevant sense of "reduced" here is that testimonial knowledge is simply a species of some other kind of knowledge. For example, standard Humean reductionism holds that testimonial knowledge is merely a species of inductive knowledge. 5 If reductionism is true, then there is nothing epistemically special about testimonial knowledge-the epistemology of testimony is just the epistemology of induction. On the contrary, anti-reductionism holds that testimonial knowledge is special, requiring its own theoretical treatment.

Accordingly, we may define reductionism as follows:

Reductionism: Testimonial knowledge is merely a species of (and is in that sense reducible to) some other kind of knowledge, for example inductive knowledge.

Anti-reductionism, then, is the denial of Reductionism:

Anti-Reductionism: At least some testimonial knowledge is not merely a species of some other kind of knowledge. For example, not all testimonial knowledge is inductive knowledge.

For present purposes, it is important to note that anti-reductionism, so understood, entails that the standards for testimonial knowledge in general are not the same as the standards for inductive knowledge in general. At least some testimonial knowledge satisfies different standards from those associated with inductive knowledge.

The next thing to note is that, whereas Reductionism is defined with a universal quantifier, Anti-Reductionism is (and should be) defined with an existential quantifier. That is because Anti-Reductionism is simply the denial of Reductionism. Of course, Anti-Reductionism is consistent with the position that all testimonial knowledge is distinct from inductive knowledge, but in fact this would be an implausibly strong position. For it seems clear that, at least in some cases, a hearer knows on the basis of testimony only because she has good inductive evidence that what the speaker testifies is true. Here are two such cases.

Police Investigator. A police investigator is interviewing a suspect in a criminal case and the suspect testifies that she is unaware that the crime has occurred. The investigator follows up with further questions and, eventually, judges that the suspect is telling the truth.

Job Applicant. A personnel director is interviewing a job applicant and the applicant testifies that he has extensive experience in sales. The personnel director follows up with further questions and, eventually, judges that the job applicant is telling the truth.

Let us further suppose that, in some such cases, the hearer may come to know that the speaker is telling the truth. But if so, that is only because the hearer has adequate evidence of the relevant sort. That evidence might include extensive experience with similar kinds of interviews, or relevant background knowledge regarding the speaker, or some other kind of relevant evidence. But in such cases, it looks like we are dealing with the same kinds of evidence and evidential standards that are relevant for inductive knowledge generally. If the hearer knows, it is because she has good inductive evidence regarding the point in question.

Contrast these cases with a third:

Good Friends. Two good friends are talking and the first tells the second that he is going for a job

For a survey, see Greco (2012)

4 For example, see C.A.J. Coady's early and influential formulation, Testimony: A Philosophical Study (Oxford: Oxford University Press 1992). See also Greco (2012); and Greco (2020)

5 See Coady, op. cit., p. 79 
interview later in the week. He also says that he feels good about his chances, because he has extensive experience in sales. The second friend believes that the first is telling the truth.

The present point is that any plausible Anti-Reductionism will treat this third case differently from the first two. Depending on the version of Anti-Reductionism at issue, the difference will be that the third case involves a special kind of trust, or assurance, or address, or speech act, or norms of cooperation, etc. ${ }^{6}$ But whatever the view, the essential point will be that some testimonial knowledge requires some such special treatment, not that all testimonial knowledge does. Again, the essential point of Anti-Reductionism is that not all testimonial knowledge is just more inductive knowledge. It is perfectly consistent with Anti-Reductionism that some testimonial knowledge is. ${ }^{7}$

Accordingly, we may define "plausible anti-reductionism" as follows:

Plausible Anti-Reductionism: Some testimonial knowledge is a species of inductive knowledge (and therefore shares similar standards) and some is not.

Anti-Reductionism in the epistemology of testimony is best understood as Plausible Anti-Reductionism.

\section{Interest relativism and knowledge attributions.}

We said that Interest Relativism about knowledge attributions is the thesis that the standards for knowledge attributions are relative to practical contexts. We can better understand the commitments of Interest Relativism by considering its two most prominent versions: Attributor Contextualism and Subject Sensitive Invariantism.

Attributor Contextualism is a meta-linguistic thesis about the semantics of "knows," and hence the semantics of sentences containing "knows" and its cognates. According to Attributor Contextualism, the truth-values of sentences of the form 'S knows that $p$ ' (and the like) are variable across conversational context. That is, two speakers, engaging in different conversations, can each utter the same sentence "S knows that p," whereby the first says something true and the second says something false. Importantly, this can be the case while keeping the values of ' $S$ ' and ' $p$ ' constant. 8

On standard versions of Attributor Contextualism, the truth-values of such sentences are variable across conversational contexts because the standards for "knows" are relative to practical contexts. Standards Contextualism is often motivated by the consideration of pairs of cases, the first of which involves a "high stakes" practical context and the second of which involves a "low stakes" practical context. The idea is that "knows" takes on higher standards in higher stakes contexts. ${ }^{9}$

We may further clarify Attributor Contextualism by making a distinction between a conversational context and a practical context. A conversational context is a situation in which some conversation is taking place. A practical context is a situation

6 For example, see Edward Hinchman, "Telling as Inviting to Trust," Philosophy and Phenomenological Research, 70:3 (2005): 562-587: Richard Moran, "Getting Told and Being Believed," in Jennifer Lackey and Ernest Sosa, eds., The Epistemology of Testimony (Oxford: Oxford University Press, 2006): Paul Faulkner, Knowledge on Trust (Oxford: Oxford University Press, 2011); Benjamin McMyler, Testimony, Trust, and Authority (New York, NY: Oxford University Press, 2011); Peter Graham, "Epistemic Normativity and Social Norms," in David Henderson and John Greco, eds., Epistemic Evaluation: Purposeful Epistemology (Oxford: Oxford University Press, 2015): pp. 247-273; Richard Moran, The Exchange of Words: Speech, Testimony, and Intersubjectivity (New York: Oxford University Press, 2018); and Greco (2020)

7 This is explicit in Stephan Wright, "In Defence of Transmission," Episteme 12, 1 (2015): 13-28. Paul Faulkner makes essentially the same point with different terminology, by distinguishing between "knowledge from testimony" and "testimonial knowledge." See Faulkner, op. cit. See also Greco (2020).

8 More explicitly, Attributor Contextualism holds that two speakers can each utter the same sentence "S knows that $p$ at time t," whereby the first says something true and the second says something false, while keeping the values of 'S', ' $p$ ', and 't' constant. Without this additional index to same time. Attributor Contextualism would be trivial. Obviously, the same person can know that p at one time and not know that $p$ at another. Below I will follow the usual practice of leaving indexes to same time implicit. For some early defenses of attributor contextualism, see Stewart Cohen, "Knowledge, Context, and Social Standards," Synthese 73 (1987): 3-26; Keith DeRose, "Solving the Skeptical Problem," The Philosophical Review (1995) 104: 1-52; David K. Lewis, "Elusive knowledge," Australasian Journal of Philosophy (1996) 74. 4: 549-56; Cohen, "Contextualist Solutions to Epistemological Problems: Scepticism, Gettier, and the Lottery." Australasian Journal of Philosophy (1997) 76: 289-306; and DeRose, The Case for Contextualism (Oxford: Oxford University Press, 2009).

9 If we interpret "standards" and "practical context" broadly, any plausible version of Attributor Contextualism will be a standard version Attributor Contextualism. However, plausible versions of Attributor Contextualism need not be motivated by high stakes/ low stakes cases, as there are other reasons why standards might vary with practical contexts. This becomes apparent in Section 3. 
in which various practical interests, needs and concerns are in play. So as not to conflate the two senses of "context," going forward we will adopt the terminology of conversational contexts and practical environments. The central idea of Attributor Contextualism, then, is that different conversational contexts pick out different practical environments, which in turn determine different standards for "knows."

Accordingly, we may define Attributor Contextualism as follows:

Attributor Contextualism: The truth-values of knowledge attributions (i.e., sentences of the form 'S knows that p', and the like) are variable across conversational contexts. Moreover, the truth-values of knowledge attributions are variable across conversational contexts because the standards for "knows" are relative to practical environments.

Using this same terminology, we may define Interest Relativism about knowledge attributions as follows:

Interest Relativism: The standards for knowledge attributions are relative to practical environments.

We may pause to note that Attributor Contextualism is a version of Interest Relativism, insofar as the former entails that the standards for knowledge attributions are relative to practical environments.

Subject Sensitive Invariantism is a different version of Interest Relativism. This second position agrees with Attributor Contextualism that the standards for knowledge attributions are relative to practical environments. It is for this reason that Subject Sensitive Invariantism is a version of Interest Relativism. In contrast to Attributor Contextualism, however, Subject Sensitive Invariantism holds that it is the practical interests of the subject that determine which standards for knowledge attributions are relevant. The result is that, although the standards for knowledge attributions are relative to the practical environment of the subject, the truth-values for knowledge attributions do not vary across conversational contexts. That is, for any given knowledge attribution, the standards that determine the truth-value of "S knows that p" are determined by S's practical interests, and so are the same relative to any context of attribution. It is in this sense that Subject Sensitive Invariantism is a form of invariantism-according to the view, the truth-values of knowledge attributions do not vary across conversational contexts. ${ }^{10}$

We saw above that Attributor Contextualism is a meta-linguistic thesis-it is primarily about the semantics of knowledge language. On standard presentations, Subject Sensitive Invariantism is also about knowledge itself. The central idea is that the standards for knowledge are relative to the practical interests of the knower. Nevertheless, Subject Sensitive Invariantism is also about knowledge attributions, where, as above, knowledge attributions are understood as linguistic entities, as the linguistic vehicles for ascribing knowledge. Straightforwardly, the standards for knowledge attributions are relative to practical environments because the standards for knowledge are relative to the subject's practical interests.

Accordingly, we may define Subject Sensitive Invariantism as follows:

Subject Sensitive Invariantism: The standards for knowledge attributions are relative to practical environments, because the standards for knowledge are relative to practical environments. Moreover, this is because the standards for knowledge are determined by the subject's practical interests. Accordingly, the truth-values of knowledge attributions are not variable across conversational contexts.

Attributor Contextualism and Subjective Sensitive Invariantism, then, are both versions of Interest Relativism. In effect, the two views agree that the standards for knowledge attributions are relative to practical environments, but give different explanations for why this is so. According to 
Attributor Contextualism, different conversational contexts pick out different practical environments, and different practical environments determine different standards for knowledge attributions. According to Subjective Sensitive Invariantism, the standards for knowledge are partly determined by the practical interests of the subject, and this entails that the standards for knowledge are relative to practical environments. But this, in turn, entails that the standards for knowledge attributions are relative to practical environments.

Finally, consider a position that denies Interest Relativism. In the contemporary literature, Attributor Contextualism and Subjective Sensitive Invariantism are often contrasted with Traditional Invariantism. ${ }^{1}$ Traditional Invariantism is a version of invariantism -it denies that the truth-values of knowledge attributions are variable across conversational contexts. But in this case, invariantism is achieved by denying Interest Relativism. The central idea is that the standards for knowledge, and therefore the standards for knowledge attributions, are independent of practical interests, whether those be the practical interests of the subject, or any other aspect of the practical environment. And because the standards for knowledge are independent of practical interests, they remain the same across different practical environments. Likewise, regarding the standards for knowledge attributions.

Accordingly, we may define Traditional Invariantism this way:

Traditional Invariantism: The standards for knowledge attributions are not relative to practical environments, because the standards for knowledge are not relative to practical environments. Moreover, this is because the standards for knowledge are independent of practical interests. Accordingly, the truth-values of knowledge attributions are not variable across conversational contexts.

With these several positions now clearly in view, we may now turn to an argument that Anti-Reductionism entails Interest Relativism.

\section{Anti-Reductionism implies Interest Relativism}

The argument begins by considering an implication of Anti-Reductionism. Namely, if Anti-Reductionism is true, then different hearers are subject to different standards for testimonial knowledge. For recall, on that view, some testimonial knowledge is merely a species of inductive knowledge and some is not. But that entails that some testimonial knowledge is subject to the standards of inductive knowledge and some is not.

This does not yet imply Interest Relativism, however. That is because Interest Relativism is the view that the standards for knowledge attributions are relative to practical environments, and Anti-Reductionism, at least as defined above, is silent on that point. But consider: on any plausible anti-reductionist view, the reason that the standards for testimonial knowledge are sometimes those of inductive knowledge and sometimes not, is due to differences in the hearer's practical environment. That is, sometimes features of the hearer's practical environment make the standards for inductive knowledge appropriate, and sometimes they make anti-reductionist standards appropriate.

That will be true on any plausible anti-reductionist view, and it is illustrated by the cases from Section 1. Thus, it is the practical environment described in Police Investigator that makes the standards of inductive knowledge appropriate. Likewise for the practical environment described in Job Applicant. Accordingly, it was argued, any plausible anti-reductionist view should acknowledge that some testimonial knowledge is subject to the standards of inductive knowledge more generally. However, if anti-reductionism is true, then not all testimonial knowledge is like this. In the practical environment described by Good Friends, for example, the quality of evidence appropriate to inductive knowledge is not required.

Different anti-reductionist views will vary on the details, but all will agree on the basic point. That is, given the practical features constituting the hearer's (and speaker's) environment, inclu-

11 For example, see Hawthorne, op. cit., and Stanley, op. cit. See also Jeremy Fantl and Matthew McGrath, Knowledge in an Uncertain World, New York: (Oxford University Press, 2009). 
ding such things as the hearer's role within that environment, and the relationship between the speaker and the hearer, anti-reductionist standards for testimonial knowledge are appropriate. Depending on the version of anti-reductionism at issue, the difference will be that this third case involves a special kind of trust, or perhaps some appropriate form of cooperation. But independently of these details, it will be some such features of the hearer's (and speaker's) practical environment that make the difference.

These considerations are sufficient to establish that Anti-Reductionism in the epistemology of testimony implies Interest Relativism about knowledge attributions. In sum: If Anti-Reductionism is true, then some testimonial knowledge is subject to the standards of inductive knowledge and some is not. And therefore, if Anti-Reductionism is true, then the standards for testimonial knowledge are variable. Moreover, if Anti-Reductionism is true, then the standards for testimonial knowledge are variable because the standards for testimonial knowledge are relative to the hearer's practical environment. Therefore, if Anti-Reductionism is true, then Interest Relativism is true.

\section{Section 4. Does Anti-Reductionism imply Attributor Contextualism?}

We next consider an argument for a stronger thesis-that Anti-Reductionism implies Attributor Contextualism. The central idea is that, if Anti-Reductionism is true, then a particular kind of case is possible. Namely, it is possible for the same hearer to occupy multiple practical contexts, and to be subject to different standards for testimonial knowledge, depending on which practical context is relevant. Next, it is argued that such a case is consistent with Attributor Contextualism, but inconsistent with the standard competitors to Attributor Contextualism-Traditional Invariantism and Subject Sensitive Invariantism. Accordingly, it would seem that Anti-Reductionism implies Attributor Contextualism.

Here is such a case:

Job Applicant and Friend. A personnel director is interviewing a job applicant and the applicant testifies that he has extensive experience in sales. But in this case, the two are also good friends. The personnel director fails to follow up with further questions, but nevertheless judges that the job applicant (his good friend) is telling the truth.

Suppose that the personnel director's name is Henry and that the job applicant's name is Sean. Does Henry know that Sean has extensive experience in sales? Anti-Reductionism is committed to saying that it depends on the practical environment, and on the standards for testimonial knowledge that the practical environment makes relevant. In Job Applicant and Friend, however, there are two practical environments to considerone constituted by the friendship between Henry and Sean, and one constituted by Henry's role as a personnel director and Sean's role as a job applicant. Which one is relevant for determining relevant standards? Anti-Reductionism, as such, does not say. Nevertheless, Anti-Reductionism does seem committed to the following, assuming that we fill in the details of the case in normal ways: Relative to the standards for testimonial knowledge associated with their friendship. Henry does know that Sean has extensive experience in sales. And relative to the standards for testimonial knowledge associated with Henry's role as a personnel director, Henry does not know.

The next step in the argument is to show that Attributor Contextualism is perfectly consistent with these Anti-Reductionist commitments. And in fact, Attributor Contextualism gives a natural and complementary account of the case.

According to Attributor Contextualism, the same knowledge attribution can have different truth values, relative to different contexts of attribution. More specifically, different conversational contexts make different practical environments relevant, and these different practical environments determine different standards for the knowledge attribution in question. For example, suppose that the conversational context is a discussion among good friends. Let us suppose that a third friend, Frederica, asks Henry whether Sean has experience in sales, and Henry answers, "Yes, I know that he does-he told me so." In this case, let us suppose, the practical environment involves 
relevant relations of trust and cooperation, making anti-reductionist standards for testimonial knowledge relevant. Relative to this practical environment, the knowledge attribution comes out true.

Now consider the same knowledge attribution, made in a different conversational context-a discussion between Henry and his boss, Beatrice. Beatrice asks Henry whether Sean has experience in sales, and Henry answers, "Yes, I know that he does-he told me so." Beatrice might take pause. "Really, he told you so?" And Beatrice would be right to take pause. Because the practical environment picked out by this conversational context does not involve relevant relations of trust or cooperation, and so anti-reductionist standards for testimonial knowledge are not relevant here.12 In fact, relative to this practical environment, it is plausibly the standards for inductive knowledge that apply, and so the knowledge attribution comes out false.

Attributor Contextualism, then, is perfectly consistent with Anti-Reductionism's commitments regarding Job Applicant and Friend. Moreover, the position adds a plausible explanation regarding how different practical environments determine the standards for different knowledge attributions, or even the same knowledge attribution associated with multiple practical environments.

What about alternative positions? First, it would seem that Standard Invariantism is inconsistent with the case as Anti-Reductionism understands it. That is because Standard Invariantism denies that the standards for knowledge are relative to practical interests, and so it must deny that the standards for testimonial knowledge are different relative to the two practical environments described in the case. Accordingly, Standard Invariantism must deny that Henry knows relative to the standards for testimonial knowledge associated with one of those practical environments, and does not know relative to the standards associated with the other. This is all in keeping with the results of Section 3, which included that
Standard Invariantism denies Interest Relativism.

For somewhat different reasons, Subject Sensitive Invariantism also seems inconsistent with the case as Anti-Reductionism must understand it. As we saw above, Subject Sensitive Invariantism is a form of Interest Relativism, and so accepts that the standards for knowledge are relative to practical interests. But according to the view, it is always the subject's practical interests that govern. Accordingly, it is always the subject's practical environment that determines which standards are relevant. The problem with Job Applicant and Friends, however, is that in this case the subject (Henry) occupies more than one practical environment. Subject Sensitive Invariantism, therefore, does not have the resources for saying which of the two practical environments described in the case is the relevant one for determining the standards for knowledge. ${ }^{13}$ For similar reasons, the view cannot make sense of the Anti-Reductionist commitment that Henry knows relative to the standards associated with one of those practical environments, and does not know relative to the standards associated with the other.

Does this mean that Anti-Reductionism implies Attributor Contextualism? No, because the alternative positions that we have so far considered do not exhaust the logical space. In particular, Stephen Grimm has recently defended a position that combines Interest Relativism and Invariantism, and that does seem consistent with the kind of case under consideration. ${ }^{14}$ According to Grimm's "Rising Tides" view, the standards for knowledge attributions are relative to practical interests, and so the view is a version of Interest Relativism. Moreover, relevant standards take into consideration the practical interests of the subject, but also those of the attributor and other parties. In that sense, the view rejects Subject Sensitive Invariantism and is similar to Attributor Contextualism. However, the Rising Tides view achieves invariantism by a different route-among competing standards

\footnotetext{
12 That is, they are not relevant to the testimonial exchange between Sean and Henry. They plausibly are relevant to the exchange between Henry and Beatrice, who are cooperating in the context.

13 This recalls a standard objection to subject sensitive invariantism. For example, see DeRose (2005).

14 Stephen Grimm, "Knowledge, Practical Interests, and Rising Tides." In David Henderson and John Greco (eds.), Epistemic Evaluation: Purposeful Epistemology (Oxford: Oxford University Press, 2015)
} 
associated with various practical interests, it is the highest standards that govern.

Here is Grimm:

it seems that our judgments about knowledge are sensitive not just to the practical concerns of the subject and not just to our own concerns as evaluators; in addition, it seems, they are sensitive to the concerns of certain third parties as well. It therefore seems that the best way-perhaps the only way-to take all of these judgments at face value is to claim that our judgments about knowledge are sensitive to the highest of these stakes In other words, to accept something along the lines of the "rising tides" account an account on which rising costs either for the subject or for the evaluator or for certain third parties can raise the thresholds relevant to knowledge. ${ }^{15}$

Accordingly, we can define the Rising Tides view as follows:

Rising Tides: The standards for knowledge attributions are relative to practical environments, because the standards for knowledge are relative to practical environments. Moreover, the standards for knowledge are determined by the strictest standards associated with various relevant practical environments.

We saw that Anti-Reductionism carries the following commitments regarding Job Applicant and Friend:

Whether Henry knows that Sean has extensive experience in sales depends on the practical environment, and on which standards for testimonial knowledge the practical environment makes relevant.

Relative to the standards for testimonial knowledge associated with their friendship, Henry does know that Sean has extensive experience in sales.

Relative to the standards for testimonial knowledge associated with Henry's role as a personnel director, Henry does not know.

Put differently, Anti-Reductionism entails that a certain kind of case is possible-one in which a hearer occupies multiple practical environments, and where commitments 1-3 apply.

We may now see that both Attributor Con- textualism and Rising Tides are consistent with these commitments and with the possibility of such a case. In effect, the two positions give different explanations regarding how the standards for knowledge attributions, and therefore their truth-values, are determined by practical interests. According to Attributor Contextualism, a conversational context picks out a relevant practical environment, which in turn determines relevant standards. Accordingly, the truth-values of the same knowledge attribution can vary across conversational contexts. According to Rising Tides, the subject of any knowledge attribution potentially interacts with a variety of persons of varying practical interests, which in turn determine a variety of standards for knowledge. Of these, the strictest standards govern. Accordingly, the truth-values of knowledge attributions do not vary across conversational contexts.

As far as these considerations go, then, Anti-Reductionism in the epistemology of testimony does not imply Attributor Contextualism about knowledge attributions. Is there some other reason why Anti-Reductionism favors Attributor Contextualism over the Rising Tides view? I believe that there is. Namely, an important motivation for Anti-Reductionism-perhaps the most compelling motivation for that view-also motivates Attributor Contextualism, but not Rising Tides. Put differently, even if Anti-Reductionism does not strictly imply Attributor Contextualism, the motivations for adopting Anti-Reductionism create pressure for adopting Attributor Contextualism as well.

Consider, then, what is perhaps the most compelling motivation for adopting Anti-Reductionism in the epistemology of testimony. Namely, that testimonial exchanges often take place in contexts of cooperation, and that this basic fact has implications regarding the norms and standards that govern such exchanges. Different anti-reductionist views articulate this important insight in different ways, but one way of doing so is to highlight a distinction between the generation of knowledge and the transmission of knowledge, and to emphasize the special role of testimony in

15 Grimm, op. cit., p. 126 
knowledge transmission. ${ }^{16}$ Very roughly, knowledge generation is about knowledge productionabout bringing knowledge into the community of knowers for the first time. Knowledge transmission, on the other hand, is about sharing the knowledge that we already have. Like other kinds of sharing, this is essentially a cooperative activity, and is therefore governed by norms and standards that reflect this. Even this very general picture, I want to argue, makes a compelling case for the essential thesis of Anti-Reductionism-that some testimonial knowledge is not reducible to, and therefore not subject to the same standards as, other kinds of knowledge.

Contrast this with motivation for the Rising Tides view. Grimm motivates this view by emphasizing that practical interests can involve higher or lower stakes, and by arguing that the standards for knowledge ought to reflect this. The basic idea is that higher stakes demand higher standards. But given that different persons are faced with different practical interests, whose stakes matter? Grimm's thought is that knowledge should be of high enough quality to serve anyone who might need it, and so the highest standards should govern: "when we judge that a belief amounts to knowledge we are judging that the belief is reliable enough not only given our first-person interests and concerns, but given the interests and concerns of third parties who might come to depend upon the belief as well."17 Hence, "our judgments about knowledge are sensitive to the highest of these stakes, whether the stakes are those of the subject, or of the evaluator, or of some third party."18

Grimm's view ties higher standards to higher stakes, but this particular point does not seem essential to his core motivation for the view. Rather, the driving ideas are a) that different practical interests require different standards for knowledge, b) that knowledge should be of high enough quality to serve all who might need it, and c) that the highest standards will achieve that purpose. That is, the highest standards will yield knowledge of high enough quality to serve the practical needs of all who might need it. In that sense, a rising tide lifts all boats.

If we apply Grimm's reasoning here to Job Applicant and Friend, we get the result that the stricter standards associated with Henry's role as personnel director apply, and so Henry does not know that Sean has extensive experience in sales. Importantly, this is so relative to any conversational context, including the conversation among friends. So, when Frederica asks Henry whether Sean has experience in sales, and Henry answers, "Yes, I know that he does," this self-attribution of knowledge by Henry is false.

My own intuition is that Rising Tides gives the wrong result here. But that is not what is presently at issue. Rather, the present question is whether Rising Tides can accommodate the most important motivation for Attributor Contextualism-that some testimonial exchanges take place in contexts of cooperation, and are therefore governed by anti-reductionist norms and standards that reflect this. It seems clear that the answer is no. On the contrary, the Rising Tides view dictates that the stricter standards associated with Henry's role as personnel director trump the anti-reductionist standards associated with his friendship, and so the stricter standards apply even relative to that context. This is in contrast to Attributor Contextualism, which easily accommodates the idea that the anti-reductionist standards ought to govern in the one conversational context, and the stricter standards ought to govern in the other. ${ }^{19}$

\section{Conclusions}

In conclusion, I have argued that Anti-Reductionism in the epistemology of testimony implies

\footnotetext{
16 Other ways of articulating the "cooperation insight," consistent with this one, are to stress the importance of trust, and to characterize testimonial exchanges in terms of joint intention and agency. See Greco (2020).

17 Grimm, op. cit., p. 131. Grimm glosses the "might" claim this way: "in our judgments about knowledge the "might" here is tracking the notion of what we may call a "real possibility"-that is, a possibility that we think "might actually" happen, as opposed to a possibility that we think "merely might" happen." (132) Thus, "while we do not think that to count as a knower someone's position needs to be strong enough to respect the "merely possible" elevated stakes of others, we do seem to think that his position needs to be strong enough to respect the elevated costs of those who "might actually" appeal to the belief." (134)

18 Grimm, op. cit., p. 126.

19 What about other competitor views? Are there other competitors to Attributor Contextualism that can accommodate these conside-
} 
Interest Relativism about knowledge attributions. More specifically, the former position, when wedded to two plausible assumptions, entails the latter. The first assumption is that not all testimonial knowledge is subject to anti-reductionist standards. The second is that, whether testimonial knowledge is subject to anti-reductionist standards depends on features of the practical environment in which the testimonial exchange takes place. I have also argued that, although Anti-Reductionism does not strictly imply Attributor Contextualism, the most compelling motivation for the former view-that anti-reductionist norms ought to govern testimonial exchanges in cooperative contexts-also motivates the latter over competitor positions.

Do the considerations reviewed here constitute arguments in favor of Interest Relativism and Attributor Contextualism. No, because they speak to the relationships among these positions, rather than the positions themselves. Specifically, if one adopts Anti-Reductionism, then one is committed to Interest Relativism and has good reasons for adopting Attributor Contextualism. I find a modus ponens inference attractive here, but others might opt for a modus tollens. ${ }^{20}$

\section{References}

COADY, C. A. J. Testimony: A Philosophical Study. Oxford: Oxford University Press, 1992

COHEN, Stewart. Contextualist Solutions to Epistemological Problems: Scepticism, Gettier, and the Lottery. Australasian Journal of Philosophy, IS. I.], v. 76, p. 289306, 1997.
COHEN, Stewart. Knowledge, Context, and Social Standards. Synthese, [S. I. ], n. 73, p. 3-26, 1987:

DEROSE, Keith. The Case for Contextualism, Oxford: Oxford University Press, 2009.

DEROSE, Keith. Solving the Skeptical Problem. The Philosophical Review, [S. I.], n. 104, p. 1-52, 1995.

FANTL, Jeremy and McGrath, Matthew. Knowledge in an Uncertain World. New York: Oxford University Press, 2009.

FAULKNER, Paul. Knowledge on Trust. Oxford: Oxford University Press, 2011.

GRECO, John. The Transmission of Knowledge. Cambridge: Cambridge University Press, 2020.

GRECO, John. Recent Work on Testimonial Knowledge. American Philosophical Quarterly, [S. I.], v. 49, n. 1, p. 15-28, 2012.

GRIMM, Stephen. Knowledge, Practical Interests, and Rising Tides. In: David Henderson and John Greco (ed.). Epistemic Evaluation: Purposeful Epistemology. Oxford: Oxford University Press, 2015.

HAWTHORNE, John. Knowledge and Lotteries. Oxford: Oxford University Press, 2004

HINCHMAN, Edward. Telling as Inviting to Trust. Philosophy and Phenomenological Research, [S. I.], v. 70, n. 3. p. $562-587,2005$

LEWIS, David K. Elusive knowledge. Australasian Journal of Philosophy, [S. I.], v. 74, n. 4, p. 549-56, 1996.

MACFARLANE, Jonathan. The Assessment Sensitivity of Knowledge Attributions. In: GENDLER, Tamar; HAWTHORNE, John (ed.). Oxford Studies in Epistemology. Oxford: Oxford University Press, 2005. v. 1, p. 197-233.

MCMYLER, Benjamin. Testimony, Trust, and Authority. New York, NY: Oxford University Press, 2011.

GRAHAM, Peter. Epistemic Normativity and Social Norms. In: HENDERSON, David; GRECO, John (ed.) Epistemic Evaluation: Purposeful Epistemology. Oxford: Oxford University Press, 2015. p. 247-273

rations about motivation? The answer is plausibly no, because our survey has now exhausted the possible space. For consider: Either a view allows that the truth-values of knowledge attributions can vary across conversational contexts or it does not. If it does, then it is a version of Attributor Contextualism. If it does not, then it is a version of Invariantism. Given that a view is a version of Invariantism, does it allow that the standards for knowledge attributions are relative to practical environments or not? If not, then it denies Interest Relativism and is therefore inconsistent with Anti-Reductionism. That leaves versions of Invariantism that embrace Interest Relativism. Among these, there are three possibilities: a) it is only the subject's practical environment that determines relevant standards, b) the subject's practical environment can matter for determining relevant standards, but so can the practical environments of others, and c) the subject's practical environment never matters for determining relevant standards-only the practical environments of others do. The first of these options is Subject Sensitive Invariantism. The second includes the Rising Tides. Moreover, it would seem that any other view in this second space would be subject to the same considerations that were brought against Rising Tides. That is, because this second kind of view is a kind of Invariantism, it will fail to accommodate the Anti-Reductionist idea that cooperative contexts call for anti-reductionist standards for testimonial knowledge. Specifically, the view will allow that stricter standards can trump anti-reductionsist standards, and so will rule that Henry does not know, even relative to the conversational context in which he is speaking with friends. (The second option plausibly includes MacFarlane's "assessment relativism," which makes the truth-value of knowledge attributions relative to a context of assessment rather than a conversational context. See, Jonathan MacFarlane, "The Assessment Sensitivity of Knowledge Attributions." In Oxford Studies in Epistemology. Vol. 1, ed. Tamar Gendler and John Hawthorne (ed.) (Oxford: Oxford University Press, 2005): 197-233.) What about the third view? It seems that there are no examples of it in the literature, perhaps because it is independently implausible. But in any case, the same considerations would apply.

20 Thanks to Wayne Davis, Stephen Grimm and Joe Salerno for helpful conversations. 
MORAN, Richard. The Exchange of Words: Speech, Testimony, and Intersubjectivity. New York: Oxford University Press, 2018.

MORAN, Richard. Getting Told and Being Believed. In: LACKEY, Jennifer; SOSA, Ernest (ed.). The Epistemology of Testimony. Oxford: Oxford University Press, 2006.

STANLEY, Jason. Knowledge and Practical Interests. Oxford: Oxford University Press, 2005.

WRIGHT, Stephan. In Defence of Transmission. Episteme, [S. I.], v. 12, n. 113-128, 2015.

\section{John Greco}

John Greco holds the Robert L. McDevitt, K.S.G., K.C.H.S. and Catherine H. McDevitt L.C.H.S Chair in Philosophy at Georgetown University. His publications include The Transmission of Knowledge (CUP 2020); Achieving Knowledge: A Virtue-theoretic Account of Epistemic Normativity (CUP 2010) and Putting Skeptics in Their Place: The Nature of Skeptical Arguments and Their Role in Philosophical Inquiry (CUP 2000). He was the editor of American Philosophical Quarterly from 2013 through 2020.

\section{Mailing adress}

\section{John Greco}

Department of Philosophy

Georgetown University

Washington, DC 20057, USA (Estados Unidos)

Os textos deste artigo foram conferidos pela Poá Comunicação e submetidos para validação do autor antes da publicação. 